\title{
A study of the disability impact among parents of mentally challenged children
}

\author{
Sunitha V., Murthy Y.V. Siva² \\ ${ }^{1}$ Dr. V. Sunitha, Professor of Pediatrics, ${ }^{2}$ Dr. Y. V. Siva Sankara Murty, Professor of Pediatrics; both authors are \\ affiliated with Maharajah's Institute of Medical Sciences, Vizianagaram, Andhra Pradesh.
}

Corresponding Author: Dr. Y. V. Siva Sankara Murty, Professor of Pediatrics, Maharajah's Institute of Medical Sciences, Vizianagaram, Andhra Pradesh. E-mail: yvssmurty@hotmail.com

\begin{abstract}
Back ground: The child with mental retardation has special needs in addition to the regular needs of all children, and parents can find themselves over whelmed by various medical, care giving, financial and educational responsibilities. Government of India, "The National Policy on Mental Handicap", has emphasized the importance of home-based care with parents as partners in the care process. Aim: To understand the positive and negative effects on parents of Mentally Retarded children by using National Institute for the Mentally Handicapped Disability Impact Scale (NIMH-DIS). Material and methods: Two intelligence tests [Vineland Social Maturity Scale (VSMS) and Developmental Screening Test (DST)] have been selected. Study sample is selected by purposive sampling method and categorized into three groups. Results: Parents of Mentally retarded children are impacted more by lifting \& carrying the child (percentage of obtained score $=41.7$ ), toileting (percentage ofobtained score $=40.6$ ) and bathing (percentage of obtained score $=40$ ). Maximum negative impact is on physical care (percentage of NIMH-DIS score $=35.5$ ), followed by financial (percentage of NIMH-DIS score = 33.9) and loss of support (percentage of NIMH-DIS score $=33$ ). Conclusion: It is not necessary for every parent having a Mental Retardation child to have negative impact but in some this can bring a positive impact, like acceptance of the situation realistically and standing right behind the Mental Retardation child to provide support.
\end{abstract}

Key words: Mental Retardation, (NIMH-DIS), SDSSQ and Intelligent Quotients.

\section{Introduction}

The birth of a baby is singularly, the most important joyous occasion in the life of any parent. Many parents hold out a lot of hopes for the future of their children, but when faced with the scenario of a child with special needs or intellectual handicap, they go through a whole lot of emotions including disappointment, resentment, a sense of guilt and a fear for the future of the child.

Raising such a child requires emotional strength and flexibility. The child with mental retardation has special needs in addition to the regular needs of all children, and parents can find themselves over whelmed by various medical, care giving, financial and educational responsibilities. It does not imply that birth of a mentally retarded child has a negative impact on all parents as in some it has been observed to have a positive influence on their personality, bringing out a

Manuscript received: $10^{\text {th }}$ September 2018

Reviewed: $20^{\text {th }}$ September 2018

Author Corrected: $28^{\text {th }}$ September 2018

Accepted for Publication: $3^{\text {rd }}$ October 2018 hitherto hidden mental strength in rising to the occasion and forming a firm support base for their child. This adaptation mechanism on behalf of the parents is inturn dependent on several personal and social factors including the psychological makeup of the parents, their education, attitudes, religious beliefs, social support system and monetary aspects.

American Association of Mental Deficiency (ASMD), has defined mental retardation as a "significantly sub average general intellectual functioning, resulting or associated with concurrent impairment in adaptive behavior and ismanifested during the developmental period" [1]. In Indian scenario, nearly $2 \%$ of the population is constituted by persons with mental retardation [2], and its prevalence varies from 0.22-32.7 per thousand populations [2,3]. The present study was undertaken with a view to understand all the factors that have a positive or negative impact on parents of mentally retarded children so that the same can be 


\section{Original Research Article}

applied to bring about a behavior modification and promote better coping strategies among parents with stress.

\section{Material}

Source of data- All the mentally retarded children between the age groups of 5-15 years, coming to the O.P.D and diagnosed using the ICD-10 criteria, with their IQ level less than 70, as assessed with the help of clinical psychologist using the intelligence tests [Vineland Social Maturity Scale (VSMS) and Developmental Screening Test (DST)] were selected. Both the parents of such children, were included in the study after obtaining a written consent from them. Information is gathered about these children and their parents on a self-designed semi-structuredquestionnaire.

\section{Methods}

Study design: Single stage cross sectional study.

Study setting: Pediatric Out patient department at Maharajah's Institute of Medical Sciences, Vizianagaram

Study population: Study sample was selected by purposive sampling method and categorized into three groups (Mild, Moderate and Severe), based on the children's Intelligent Quotient levels.

1. Mild: contains both parents (both mother and father) of 30 mild mentally retardedchildren.

2. Moderate: contains both parents (both mother and father) of 30 moderately mentally retardedchildren.

3. Severe: It contains both parents (both mother and father) of 30 severe to profound mentally retarded children.

The total study sample size is 90 and study period is 12 months

\section{Inclusion criteria}

- Parents of children aged 5-15years.

- Parents of children with IQ below70.

- Children having both the parents aretaken.

- Parents who gave their consent forstudy.

\section{Exclusion criteria}

- Children having severe/chronic physical illness.

- Parents suffering any physical or mentalillness and single parents.

- Patients who refuse to giveconsent.

Ethical considerations: Written informed consent istaken from parents of Mental Retardation children and Confidentiality is maintained. All the Subjects retained the right to withdraw consent at anystage of this study.

Sampling technique: Individuals who fulfill the inclusion and exclusion criteria are selected by purposive sampling method and the data pertaining to their socio-demographic details and clinical variables is collected using a self designed semi-structured questionnaire. A written informed consent is taken for participation after explaining the purpose and design of the study. Prior to consent, the participants are informed that refusal to participate will not affect the course of counseling or further management.

Study tools: Study tools included self-designed semistructured questionnaire and National Institute for the Mentally Handicapped Disability Impact Scale. The data pertaining to their sociodemographic details and clinical variables was collected using the self designed semi-structured questionnaire and was analyzed.

\section{Results}

Results have been discussed under the following sub-sections:
A. Socio-demographic profiles of parents.
B. Impact of mental retardation on parents of MR children
C. Impact of mental retardation on parents of MR children - based on parent's gender
D. Impact of mental retardation on parents of MR children - based on severity of mental retardation

\section{A. Socio-demographic profiles of parents.}

Major variables studied here were parent's age, sex, type of family, education, income, religion and occupation of parents. In the present study, $65.6 \%$ of parents belongedto rural areas.Majority of the parents ( $81 \%$ ) belonged to nuclear type of family structure. 
Table 1: Socio-demographic profiles.

\begin{tabular}{|c|c|c|c|c|}
\hline \multicolumn{2}{|c|}{ Self-designed semi-structured questionnaire } & Number of parents & $\%$ & $\mathbf{N}$ \\
\hline \multirow[t]{3}{*}{ Fathers occupation } & Unemployed / house Wife & 3 & 3.3 & \multirow[b]{3}{*}{90} \\
\hline & Formers / Self-employed & 54 & 60.0 & \\
\hline & Employed in some Firm & 33 & 36.7 & \\
\hline \multirow[t]{3}{*}{ Mothers occupation } & Unemployed / house Wife & 69 & 76.7 & \multirow[b]{3}{*}{90} \\
\hline & Formers / Self-employed & 18 & 20.0 & \\
\hline & Employed in some Firm & 3 & 3.3 & \\
\hline \multirow[t]{4}{*}{ Parents income } & less than 10000 & 35 & 19.4 & \multirow{4}{*}{180} \\
\hline & 10000-19999 & 31 & 17.2 & \\
\hline & $20000-29999$ & 86 & 47.8 & \\
\hline & 30000 or above & 28 & 15.6 & \\
\hline \multirow{2}{*}{$\begin{array}{c}\text { Infections during } \\
\text { Pregnancy }\end{array}$} & Absent & 87 & 96.7 & \multirow[t]{2}{*}{90} \\
\hline & Present & 3 & 3.3 & \\
\hline \multirow{2}{*}{$\begin{array}{c}\text { Attempt to induce } \\
\text { Abortion }\end{array}$} & Absent & 79 & 87.8 & \multirow[t]{2}{*}{90} \\
\hline & Present & 11 & 12.2 & \\
\hline \multirow{2}{*}{$\begin{array}{c}\text { History of repetitive } \\
\text { Abortion }\end{array}$} & Absent & 80 & 88.9 & \multirow[t]{2}{*}{90} \\
\hline & Present & 10 & 11.1 & \\
\hline \multirow[t]{3}{*}{ Fathers age at child birth } & Below 20 years & 3 & 3.3 & \multirow{3}{*}{90} \\
\hline & 21-35 years & 70 & 77.8 & \\
\hline & Above 35 years & 17 & 18.9 & \\
\hline \multirow[t]{3}{*}{ Mothers age at child birth } & Below 20 years & 20 & 22.2 & \multirow{3}{*}{90} \\
\hline & 21-35 years & 65 & 72.2 & \\
\hline & Above 35 years & 5 & 5.6 & \\
\hline \multirow[t]{3}{*}{ Nature of delivery } & Natural & 71 & 78.9 & \multirow{3}{*}{90} \\
\hline & Cesarean & 17 & 18.9 & \\
\hline & Forceps & 2 & 2.2 & \\
\hline \multirow{2}{*}{$\begin{array}{l}\text { Complications during } \\
\text { Birth }\end{array}$} & Absent & 28 & 31.1 & \multirow[t]{2}{*}{90} \\
\hline & Present & 62 & 68.9 & \\
\hline \multirow[t]{2}{*}{ Complications after birth } & Present & 14 & 15.6 & \multirow[t]{2}{*}{90} \\
\hline & Absent & 76 & 84.4 & \\
\hline \multirow[t]{3}{*}{ MR diagnosis age } & Below 5 years & 102 & 56.7 & \multirow{3}{*}{180} \\
\hline & $5-10$ years & 48 & 26.7 & \\
\hline & $10-15$ years & 30 & 16.7 & \\
\hline \multirow[t]{2}{*}{ MR child sex } & Male & 119 & 66.1 & 180 \\
\hline & Female & 61 & 33.9 & \\
\hline MR child birth order & First & 77 & 42.8 & \\
\hline & Between & 63 & 35.0 & 180 \\
\hline & Last & 40 & 22.2 & \\
\hline MR child education & Not going to school & 81 & 45.0 & \\
\hline & Preprimary & 58 & 32.2 & \\
\hline & Primary & 32 & 17.8 & 180 \\
\hline & Higher than primary & 9 & 5.0 & \\
\hline
\end{tabular}

Table 1: Self-designed semi-structured questionnaire, information was collected regarding father's and mother's occupation along with parentsincome and their ages at the time of child birth. A past history of abortions, infections during pregnancy and mode of delivery were also documented. Most of the disable children are male 66.1\% (119) diagnosed below 5 yrs $56.7 \%$ (102) with $1^{\text {st }}$ order $42.8 \%$ (77), not going to school $45.0 \%$ (81). 
B. Influence of mental retardation on parents of mentally retarded children.

NIMH-DIS had been administrated, results of which are as follows:

Table-2: Shows the scoring percentages of different variables in physical care domain.

\begin{tabular}{|c|c|c|c|c|c|c|}
\hline \multirow{2}{*}{$\begin{array}{c}\text { Variable in physical care } \\
\text { domain }\end{array}$} & \multicolumn{3}{|c|}{ Number of parents } & \multirow{2}{*}{ Sobt } & \multirow{2}{*}{$\%$} \\
\cline { 2 - 5 } & No difficulty & Some difficulty & Lot of difficulty & & & \\
\hline Bathing & 78 & 60 & 42 & 360 & 144 & 40.0 \\
\hline Feeding & 83 & 65 & 32 & 360 & 129 & 35.8 \\
\hline Dressing & 86 & 56 & 38 & 360 & 132 & 36.7 \\
\hline Toileting & 80 & 54 & 46 & 360 & 146 & 40.6 \\
\hline Brushing & 95 & 67 & 18 & 360 & 103 & 28.6 \\
\hline Grooming & 101 & 67 & 12 & 360 & 91 & 25.3 \\
\hline Lifting \& carrying the child & 82 & 46 & 52 & 360 & 150 & 41.7 \\
\hline Medicating & 86 & 60 & 34 & 360 & 128 & 35.6 \\
\hline Total impact & & & & $\mathbf{2 8 8 0 . 0}$ & $\mathbf{1 0 2 3 . 0}$ & $\mathbf{3 5 . 5}$ \\
\hline
\end{tabular}

Table 2: Shows the scoring percentages of different variables in physical care domain. Parents of Mentally retarded children are impacted more by lifting $\&$ carrying the child (percentage of obtained score $=41.7$ ), toileting (percentage ofobtained score $=40.6$ ) and bathing (percentage of obtained score $=40$ ). Overall percentage of scoring for physical care domain is 35.5 .

\section{Impact of mental retardation on parents of MR children - based on parent's gender}

Impact of MR on fathers and mothers are compared using NIMH-DIS, and the hypothetical z-test has been employed for comparing the scoring proportions. Results of which are reported in Table 3.

Table 3: Impact of MR on fathers and mothers are compared using NIMH-DIS

\begin{tabular}{|c|c|c|c|c|c|c|}
\hline Domain & Gender & Smax & Sobt & $\%$ & $\mathbf{Z}$ & $\mathbf{p}$ \\
\hline \multirow[t]{2}{*}{ Physical care } & Male & 1440 & 482 & 33.5 & \multirow[t]{2}{*}{-2.243} & \multirow[t]{2}{*}{0.025} \\
\hline & Female & 1440 & 541 & 37.6 & & \\
\hline \multirow[t]{2}{*}{ Health issues } & Male & 900 & 199 & 22.1 & \multirow[t]{2}{*}{-2.4152} & \multirow[t]{2}{*}{0.015} \\
\hline & Female & 900 & 243 & 27 & & \\
\hline \multirow{2}{*}{$\begin{array}{c}\text { Career } \\
\text { Adjustment }\end{array}$} & Male & 720 & 166 & 23.1 & \multirow[t]{2}{*}{6.1047} & \multirow[t]{2}{*}{$<0.05$} \\
\hline & Female & 720 & 79 & 11 & & \\
\hline \multirow{2}{*}{$\begin{array}{l}\text { Lossof } \\
\text { Support }\end{array}$} & Male & 900 & 295 & 32.8 & \multirow[t]{2}{*}{-0.1805} & \multirow[t]{2}{*}{0.857} \\
\hline & Female & 900 & 299 & 33.2 & & \\
\hline \multirow{2}{*}{$\begin{array}{c}\text { Financial } \\
\text { Problem }\end{array}$} & Male & 900 & 311 & 34.6 & \multirow[t]{2}{*}{0.6274} & \multirow[t]{2}{*}{0.529} \\
\hline & Female & 900 & 299 & 33.2 & & \\
\hline \multirow{2}{*}{$\begin{array}{c}\text { Social } \\
\text { Restriction }\end{array}$} & Male & 540 & 122 & 22.6 & \multirow[t]{2}{*}{-0.079} & \multirow[t]{2}{*}{0.936} \\
\hline & Female & 540 & 123 & 22.8 & & \\
\hline \multirow{2}{*}{$\begin{array}{c}\text { Embarrassment / } \\
\text { ridicule }\end{array}$} & Male & 720 & 128 & 17.8 & \multirow[t]{2}{*}{0.099} & \multirow[t]{2}{*}{0.921} \\
\hline & Female & 720 & 127 & 17.6 & & \\
\hline \multirow[t]{2}{*}{ Relationship } & Male & 1080 & 307 & 28.4 & \multirow[t]{2}{*}{1.099} & \multirow[t]{2}{*}{0.276} \\
\hline & Female & 1080 & 284 & 26.3 & & \\
\hline \multirow[t]{2}{*}{ Sibling effect } & Male & 1260 & 295 & 23.4 & \multirow[t]{2}{*}{-0.764} & \multirow[t]{2}{*}{0.447} \\
\hline & Female & 1260 & 311 & 24.7 & & \\
\hline \multirow{2}{*}{$\begin{array}{l}\text { Specific } \\
\text { Thoughts }\end{array}$} & Male & 720 & 240 & 33.3 & \multirow[t]{2}{*}{3.8149} & \multirow[t]{2}{*}{$<0.05$} \\
\hline & Female & 720 & 174 & 24.2 & & \\
\hline \multirow{2}{*}{$\begin{array}{l}\text { Total negative } \\
\text { Impact }\end{array}$} & Male & 9180 & 2545 & 27.7 & \multirow[t]{2}{*}{1.064} & \multirow[t]{2}{*}{0.289} \\
\hline & Female & 9180 & 2480 & 27.0 & & \\
\hline Positive & Male & 900 & 456 & 50.7 & -0.297 & 0.764 \\
\hline Impact & Female & 900 & 463 & 51.4 & & \\
\hline
\end{tabular}


Original Research Article

Table 3: With MR children Mothers are experiencing more difficulties than fathers with respect to physical care and health issues. Fathers are experiencing more trouble in career adjustments and specific thoughts. There is not much difference in the overall positive and negative impact scores among both parents.

D. Impact of mental retardation on parents of Mentally retarded children - based on severity of mental retardation

Table 4: shows results related to impact on parents of MR children based on its severity (mild, moderate and severe).

\begin{tabular}{|c|c|c|c|c|c|c|}
\hline \multirow{2}{*}{ Domain } & \multicolumn{2}{|c|}{ Mild } & \multicolumn{2}{c|}{ Moderate } & \multicolumn{2}{c|}{ Severe } \\
\cline { 2 - 7 } & Smax & Sobt & Smax & Sobt & Smax & Sobt \\
\hline Physical care & 960 & 87 & 960 & 324 & 960 & 612 \\
\hline Health & 600 & 98 & 600 & 190 & 600 & 154 \\
\hline Career & 480 & 68 & 480 & 95 & 480 & 82 \\
\hline Support & 600 & 187 & 600 & 209 & 600 & 198 \\
\hline Financial & 600 & 185 & 600 & 213 & 600 & 212 \\
\hline Social & 360 & 76 & 360 & 84 & 360 & 85 \\
\hline Embarrassment/Ridicule & 480 & 81 & 480 & 84 & 480 & 68 \\
\hline Relationships & 720 & 186 & 720 & 203 & 720 & 202 \\
\hline Sibling effect & 840 & 154 & 840 & 168 & 840 & 284 \\
\hline Specific thoughts & 480 & 117 & 480 & 141 & 480 & 153 \\
\hline Total negative impact & 6120 & 1239 & 6120 & 1711 & 6120 & 2050 \\
\hline Total positive impact & 600 & 296 & 600 & 318 & 600 & 305 \\
\hline
\end{tabular}

Table 4, shows results related to impact on parents of MR children based on its severity (mild, moderate and severe) and their relation Z-test has been used

Table-5: Showing the impact of MR on parents with respect to severity of disability.

\begin{tabular}{|c|c|c|c|c|c|c|}
\hline \multirow[t]{2}{*}{ Domain } & \multicolumn{2}{|c|}{$\begin{array}{l}\text { Mild vs. } \\
\text { Moderate }\end{array}$} & \multicolumn{2}{|c|}{$\begin{array}{c}\text { Moderatevs. } \\
\text { Severe }\end{array}$} & \multicolumn{2}{|c|}{ Mild vs. Severe } \\
\hline & $\mathbf{z}$ & $\mathbf{P}$ & $\mathbf{z}$ & $\mathbf{p}$ & $\mathbf{z}$ & $\mathbf{P}$ \\
\hline Physical care & -13.18 & $<0.05$ & -13.14 & $<0.05$ & -24.90 & $<0.05$ \\
\hline Health & -6.246 & $<0.05$ & 2.297 & $<0.05$ & -3.997 & $<0.05$ \\
\hline Career & -2.310 & 0.021 & 1.078 & 0.280 & -1.237 & 0.215 \\
\hline Support & -1.326 & 0.184 & 0.659 & 0.509 & -0.668 & 0.503 \\
\hline Financial & -1.173 & 0.084 & 0.072 & 0.944 & -1.657 & 0.097 \\
\hline Social & -0.710 & 0.478 & -0.095 & 0.928 & -0.805 & 0.418 \\
\hline Embarrassment/Ridicule & -0.675 & 0.503 & 1.627 & 0.103 & -1.717 & 0.085 \\
\hline Relationships & -1.026 & 0.303 & 0.042 & 0.968 & -0.984 & 0.327 \\
\hline Sibling effect & -0.885 & 0.373 & -6.378 & $<0.05$ & -7.237 & $<0.05$ \\
\hline Specific thoughts & -1.747 & 0.080 & -0.840 & 0.401 & -2.584 & $<0.05$ \\
\hline Total negative impact & -8.649 & $<0.05$ & -3.870 & $<0.05$ & -12.487 & $<0.05$ \\
\hline Total positive impact & -1.282 & 0.201 & 0.763 & 0.447 & -0.520 & 0.603 \\
\hline
\end{tabular}

Parents of moderate and severe mentally retarded children registered greater problems compared to those of mild mentally retarded children, for all 11 domains in NIMH-DIS. However, the difference in impact with respect to varying degree of severity is found to be minimal for most of the domains, except for career, sibling effect and specific thoughts. Total negative impact on mentally retarded children parents is with direct relation to the severity of mental retardation. Whereas, the positive impact levels with respect to degree of severity was insignificant. 


\section{Discussion}

Present study was conducted on parents of 90 mentally retarded children.

NIMH-DIS was used to assess the impact on them.

1. The impact in the parents of mentally retarded children is related to their socio-demographic characteristics.

2. The present study has indicated more positive impact in the parents of mentally retarded children compared to that of the negative impact.

3. Severity of MR is an important contributing factor to both the positive and negative impact in the parents of mentally retarded children. Intensity of negative impact in the parents unlike the positive impact is proportional to the severity of mental retardation.

\section{Parents response to different domains in NIMH}

Physical care: The present study revealed that $52.2 \%$ of the parents were facing difficulty (either some / lot of difficulty) with respect to physical care requirements of mentally retarded children. This observation compares favorably with the study by Brust [3], who has found that the mothers of MR children require an average time of 12 hours 6 minutes for satisfying the physical care requirements.

Health: It can be seen that $36.7 \%$ of parents in the present study were suffering with some health issues. Most of them were facing mental worries in view of having MR child. This observation is consistent with the study carried out at the Regional Rehabilitation Center (RRHC) by Gathwala and Guptha [4] which showed that $60 \%$ of families were severely burdened with respect to physical health of family members, which included physical/psychological illness and depression of the family members Career: In the present study, $74.4 \%$ of parents didn't have any impact on their career adjustments to support mentally retarded children, and the percentage of parents, who are facing some difficulty and lot of difficulties in their career is less. Similar observation has been reported by few authors in the past $[5,7]$.

Loss of support: Statistics depicting distribution of loss of support with respect to different relations, indicates that $\sim 50 \%$ of the parents felt that they are facing difficulty in getting support from relations. The study compares favorably with the observations made by other authors [8], who has found ignorance of families with mentally retarded children as the sign of social isolation of those families.

Financial problems: In the present study, $53.9 \%$ of parents (parents voted for both "some" and "lot of difficulty") were facing severe financial problems which is in par with the earlier report by Seiquira \& associates [9]. Gathwala and Guptaalso reported that $25 \%$ of the families were severely burdened by the financial needs[4].

Social restriction: Statistics of social restriction domain, evidences that $31.7 \%$ of parents (voted for both "sometimes" and "most of the times") in the present study are constrained to social movement in view of having mentally retarded children. This observation is consistent with the previous reports by Farber

Embarrassment/ ridicule: The current study resulted that more than $26.7 \%$ of the parents were facing embarrassment (parents voted for both "some" and "lot of" embarrassment) [10]. These results were also supported by the studies done by Dattaand Nancy $[11,12]$.

Relationship: Only $45.6 \%$ are thinking negatively that the presence of mentally retarded children affects their relationship with spouse / family / in-laws / relatives/ friends / neighbours.

Sibling effect: More than $60.5 \%$ of the parents in the present study were happy about their sibling's life style and carrier. This is comparable to Gohel study, who reported that higher percentage of parents felt that they were giving less time to their siblings [13].

Specific thoughts: More than 55\% of the parents in the present study had never thought of having another child, as they feel that they were unprepared to take responsibilities of another child in view of the existing struggle in rearing the MR child. Nearly $60 \%$ of the parents who sometimes thought of separating the MR child from the family, so that this child doesn't affect the rest of family members. Majumdar found that the parents of mentally retarded children were more vulnerable to stress than parents of normal children, which is in par with the present study [14]

Positive effects: More than $81.6 \%$ of the parents were having positive effect (including both groups i.e., "lot of effect" and "some effect") due to mentally retarded children. The possible explanation for the positive 
effects in the parents of MR children can be got from following studies. Positive impact has also been reported by Kazak and Marvin [15].

\section{More positive and less negative impact on parents}

Present study has shown more positive impact (percentage of NIMH-DIS score $=51.1$ ) in the parents of mentally retarded children compared to that of the total negative impact (percentage of NIMH-DIS score $=$ $27.5)$ in the same study group. This finding relates to the observation in Flahertystudy, showing parents tendency to shift from negative impact (family problem) to positive impact (family competence) with time [16].

Present study suggests that the parents are facing adverse problems in the allocation of funds [i.e., financial domain ( $2^{\text {nd }}$ highest NIMH-DIS score)] in the care and training of their mentally retarded children as well as in other necessary domestic requirements. Negative impact on the parents of the intellectually disabled children in the form of financial crisis was well reported by Datta, whichisconsistent with the present study [11].

Gender based impact of mental retardation on parents: From above discussion, it is apparent that the overall positive and negative impact scoring between mothers and fathers is not significant, with few differences noted. Key finding of these observationsare summarized as follows:

1. Mothers of mentally retarded children are experiencing more difficulties than fathers in physical care and healthdomains.

2. Fathers of mentally retarded children are experiencing more trouble in career and specific thoughtsdomain.

3. No significance is found between the parents for following domains: loss of support, financial, social restriction, embarrassment / ridicule, relationships, sibling effect and positiveeffects.

Several authors have found similar findings, which are explained below:

Rastogifound more negative attitude in case of mothers of mentally retarded children compared to fathers [17]. Fathers are concerned mainly about family budget and the cost of providing help for the MR child. These finding are in par with the Burrfinding, which revealed that the fathers of mentally retarded children tend to keep their feelings inside, and use more harmful types of strategies [18].
Original Research Article

Above findings are comparable with the study by Hellerand Upadhyaya, which reported no significant association between fathers and mothers with respect to financial aspects (financial domain) [19,20].

\section{Disability impact among varying degree of severity}

From table 4 and 5, it is evident that the intensity of various domains in NIMH-DIS by the parents of mentally retarded children has direct linkages with the level of retardation of their child. Key finding of which are summarized as follows:

1. The parents of moderate and severe mentally retarded children registered greater problems compared to those of mild mentally retarded children, for all 11 domains of NIMH-DIS.

2. Total negative impact scoring with respect to varying severity of MR is significant, with NIMHDIS scoring being high for severe mentally retarded children compared to those of the mild and the moderate mentally retarded children.

3. Positive impact scoring is not significant with respect to varying severity of MR.

The present results are at par with the results of Magra $\&$ colleagues (1999), who have stated that mothers face many challenges such as poor health to care for their loved ones with degree ofMR.

The parents with mild MR child tend to help themselves with a keep going tendency. Similar results and reasons are identified by Seiquirain relation to severe mentally retardedchildren [9].

\section{Strength of the present study}

1. The comprehensive assessment of the impact of having a mentally retarded child onparents.

2. Comparing the impact between mothers and fathers.

3. Comparing the impact based on the severity of mentalretardation.

\section{Limitations}

1. This is a one stage cross sectional study no followups weredone

2. Lack of a comparisongroup

3. Sample size issmall

The study is conducted in a Government hospital, therefore results cannot be generalized. 


\section{SUMMARY}

The current study is a cross-sectional study, intended to explore both the positive and negative impact on the parents of mentally retarded children with respect to parent's gender and severity of mental retardation by using the NIMH- DIS.

In this study, 180 parents (comprising 90 families with their fathers and mothers) with mentally retarded children were selected. Tools used were: specially designed socio-demographic data, clinical data sheet and NIMH-DIS (11 domains assessing specific parameters).

Results have shown than most of the respondents were Hindus hailing from rural background with nuclear families, more than $40 \%$ being illiterate with family income of $<$ Rs. 10000 per month. Most of the female respondents (mothers) were house wives and didn't have any history of infections during and after the pregnancy. Most children were born out of normal vaginal delivery and very few by caesariansection.

Percentage of positive impact (51.1\%) on the parents of mentally retarded children is substantially negative impact (27.4\%). Most of the parents in the present study were not considering the situation of having MR children as a burden

Conclusions.

\section{The salient features of this study are:}

1. The present study has shown that the impact levels in the parents of mentally retarded children are related to their socio-demographic characteristics.

2. This study has shown more positive impact in the parents of mentally retarded children compared to that of the negative impact irrespective of the parent'sgender.

It has been found from the present study that the degree of Mental Retardation severity is an important factor in giving rise to both positive and negative impact on the parents of mentally retarded children. Whereas, the difference of negative impact with respect to positive impact isminimal.

In conclusion, it can be inferred that it is not necessary for every parent having a Mental retardation child to have negative impact but in some this can bring a positive impact, like acceptance of the situation realistically and standing right behind the MR child to provide support. At the same time, it is also true that having a MR child is a source of severe stress to the family members and it can affect them negatively in many ways. Therefore, there is every need to make attempt for primary prevention of mentalretardation

\section{Recommendations for future work}

1. Impact of age and gender of the MR child on their parents can be considered in future, so that it could help in better utilization of interventions.

2. A longitudinal study with regular follow-up may be considered in the future for better understanding the impact levels on theparents.

3. Studies including coping interventions may be taken up in the future, helping the parents in developing coping strategies and to overcome the problems.

4. It is worthwhile to conduct a comparative study between normal and MR children to highlight the problems being suffered by the parents of MR children.

A multicentric study to be conducted, so that the results can be applied over wide range.

Funding: Nil, Conflict of interest: None initiated, Perission from IRB: Yes

\section{References}

1. WORCHEL TL, WORCHEL P. The parental concept of the mentally retarded child. Am J MentDefic. 1961 May; 65:782-8.

2. ZUK GH. The religous factor and the role of guilt in parental acceptance of the retarded child. Am J Ment Defic. 1959 Jul;64(1):139-47.

3. Brust JD, Leonard BJ, Sielaff BH. Maternal time and the care of disabled children.Public Health Nurs. 1992 Sep;9(3):177-84.

4. Gathwala.G, Gupta. S. family burden in Mentally Handicapped children. Indian Journal of community medicine 2004; vol 24No.4.

5. Booth CL, Kelly JF.Child care and employment in relation to infants' disabilities and risk factors. American Journal of Mental Retardation. 1999; March; 104(2):117-30.

6. Marji Erickson Warfield. Employment, Parenting, and Well-Being Among Mothers of Children With Disabilities Retardation 2000; Vol. 39, No. 4, pp. 297-309. 
7. Warfield ME. Employment, parenting, and wellbeing among mothers of children with disabilities. Ment Retard. 2001Aug;39 (4):297-309. doi:10. 1352/ 0047-6765(2001)039<0297:EPAWBA>2.0.CO;2

8. Samuel Bauman. Parents of children with mental retardation: coping mechanisms and support needs. Dissertation submitted to the Faculty of the Graduate School of the University of Maryland, College Park in partial fulfillment of the requirements for the degree of Doctor of Philosophy 2004.

9. Seiquira, E.M., Rao, P.M., Subbu Krishna, D.K. \& Prabhu G.G. Perceived burden and coping styles of the mothers of mentally handicapped. NIMHANS journal,1990;8(1).

10. Farber, B. Effects of a severely mentally retarded child of family integration. Monographs of the Society for Research in Child Development, 1959;24, (2, Serial No.71).

11. Datta SS, Russel PS, Gopalakrishna SC. Burden among the caregivers of children with intellectual disability: Associated risk factors. JIntellect Disab 2002; 6:337-50.

12. Nancy, G. Attitudes of parents towards their mentally retarded children: A rural area examination (master thesis). Department of Psychology University of Zululand 2002;1-68. Available from:http:// uzspace. uzulu.ac.za/handle/10530/220.

13. Gohel M., Mukherjee S., Choudhary S.K. Psychosocial impact on the Parents of mentally retarded children in Anand District, health line, 2011; Vol.2,p.62-66.
Original Research Article

14. Majumdar M, Da Silva Pereira Y, Fernandes J. Stress and anxiety in parents of mentally retarded children. Indian J Psychiatry. 2005 Jul;47(3):144-7. doi: 10.4103/0019-5545.55937.

15. Kazak AE and Marvin RS. Stress and social networks in families with a handicapped child. Fam Relat 1985; 33:67-77.

16. Flaherty, E.M., \& Glidden, L.M. Positive adjustment in parents rearing children with Down syndrome. Early Education and Development, 2000; 11, 407-422.

17. Rastogi CK. Attitude of parents towards their mentally retarded children. Indian J Psychiatry. 1981 Jul; 23 (3):206-9.

18. Burr, W.R., Klein, S.R., Burr, R.G., Doxey, C., Harker, B., Holman, T.B., Martin, P.H., McClure, R.L., Parrish, S.W., Stuart, D.A., Taylor, A.C., \& White, M.S. (1994). Reexamining family stress. Thousand Oaks, CA: Sage Publications, Inc.

19. Heller, T., Hsieh, K., Rowitz, L. Maternal and Paternal care giving of persons with mental retardation across the life span. Family relations, 1997; 46 (4),407-115.

20. Upadhyaya, G.R. and Havalappanavar, N.B. Stress in Parents of the Mentally Challenged, Journal of the Indian Academy of Applied Psychology 2008; 24, 53-59

\section{How to cite this article?}

Sunitha V, Murthy Y.V. Siva. A study of the disability impact among parents of mentally challenged children. Int J Pediatr Res. 2018;5(10):497-505. doi:10.17511/ijpr.2018.i10.04. 